BY NICOLAS VALLOIS*

\begin{abstract}
In the early twentieth century, an economic doctrine known as "non-proletarianization theory" became influential among left-wing Zionists in Russia. According to this theory, Jewish workers were unable to "proletarianize"-that is, to integrate large-scale industry; hence, Jewish territorial autonomy was required, whether in Palestine or elsewhere. This article analyzes this theory's historical development, focusing on the works of three authors: Khaim Dov Horovitz, Yakov Leshchinsky, and Ber Borochov. I claim that discussions of Jewish nonproletarianization can be considered a specific and coherent intellectual tradition in the history of economic thought. I also discuss these theories' relation to the anti-sweatshop campaign of the Progressive Era, particularly John R. Commons's writings on Jewish immigrants that were recently debated in this journal.
\end{abstract}

* CRIISEA, Université de Picardie Jules Verne. Contact: nicolas.vallois@u-picardie.fr

This "preprint" is the peer-reviewed and accepted typescript of an article that is forthcoming in revised form, after minor editorial changes, in the Journal of the History of Economic Thought (ISSN: 1053-8372), issue TBA. Copyright to the journal's articles is held by the History of Economics Society (HES), whose exclusive licensee and publisher for the journal is Cambridge University Press.

(https:/www.cambridge.org/core/journals/journal-of-the-history-of-economic-thought) This preprint may be used only for private research and study and is not to be distributed further.

The preprint may be cited as follows:

Vallois, Nicolas. "Non-Proletarianization Theories of the Jewish Worker (1902-1939)." Journal of the History of Economic Thought (forthcoming). Preprint at SocArXiv, osf.io/preprints/socarxiv 


\title{
NON-PROLETARIANIZATION THEORIES OF THE JEWISH WORKER (1902-
}

1939)

\author{
Nicolas Vallois
}

\section{INTRODUCTION}

In 1880, more than five and a half million Jews lived in Eastern Europe (DellaPergola 1997, p.21). The vast majority of this population suffered from chronic poverty. Historian Eli Lederhendler estimates that "as much as 70 percent of the Jewish labor force (at the time) must be considered the 'working poor', whether they worked at a manual trade or eked out a living in minor and ephemeral 'businesses"" (Lederhendler 2009, p.7). These socio-economic hardships related to the larger context of Imperial Russia, which became increasingly hostile toward Jews in the late nineteenth century. Most Eastern European Jews were, indeed, residents of the Russian Empire. ${ }^{1}$ The wave of pogroms that started in southwestern Russia in 1881 initiated a crisis period for Russian Jews that was marked by chronic underemployment, a population explosion, public hostility, and legal discrimination (Frankel 1984; Aronson 1990). One major restriction against Jews was the "Pale of Settlement," a region in the Western part of the Russian Empire, where Jews were forced to reside. Apart from rare exceptions, Russian Jews could not live in the more prosperous districts of central Russia (Frankel 1984; Klier and Lambroza 1992).

This socio-economic crisis prompted the development of new political movements and ideologies among Eastern European Jews-socialism and Zionism in particular, which often rivaled one another. In 1901, the Bund, the main Jewish socialist movement, passed a resolution condemning "the national feeling, which can only cloud the class consciousness of the Jewish proletariat" (quoted in Brym 1978, p.82). ${ }^{2}$ Yet, before and after the Bund's resolution, several leading figures advocated for a synthesis of socialism and Jewish nationalism, forming what is called "Socialist Zionism," "Labor Zionism," or "Marxist Zionism." Within a few years, from 1898 to 1904, numerous socialist and workers' Zionist organizations sprang up in Russia and Austria-Hungary (Frankel 1984, pp.310-311; Trachtenberg 2008, pp.36-40). During the years of revolution, 1905-1906, the movement produced three major parties: the Zionist Socialist Workers Party, founded in Odessa in 1905; the Jewish Socialist Workers Party, often nicknamed "Seymists," created in April 1906; and the "Poale Zion" ("workers of zion"), founded in Poltava in 1906.

Important ideological differences distinguished these three parties. The Seymists favored Jewish national autonomy in Russia and defended the idea of a Jewish national assembly (a Seym), the Poale Tsion remained committed to the idea of a Jewish national state in Palestine, and the Zionist Socialists supported non-Palestinian territorialism. Yet these three

\footnotetext{
${ }^{1}$ The expression "Eastern Europe" also refers, in a broad sense, to regions that were outside the Russian Empire. In particular, significant numbers of Jews lived in Habsburg Galicia, Romania, and the Balkans. Yet Russian Jews amounted to approximately 80\% of the Jewish population in Eastern Europe in 1910 (Lederhendler 2009, p.1).

${ }^{2}$ The term "Bund" stands for "General Jewish Labour Bund in Lithuania, Poland, and Russia."

${ }^{3}$ In this article, I consider these expressions as synonyms and mostly use the label "Labor Zionism." Note, however, that these expressions are not strictly equivalent since some Socialist Zionists were, for instance, not Marxist (e.g., Khaim Zhitlovsky).
} 
factions shared many ideological assumptions (Trachtenberg 2008, p.39) and agreed on a common theoretical doctrine known as "non-proletarianization" theory. ${ }^{4}$ This Marxist-inspired theory was central to left-wing Zionist ideology because it demonstrated the compatibility between socialism and Zionism. According to this theory, Jews in Eastern Europe were unable to "proletarianize" - that is, to integrate large-scale industry and form a proletarian class. As a result, socialist and proletarian goals required a form of territorial autonomy for Jews, whether in Palestine or elsewhere.

This article's thesis is that theories of Jewish non-proletarianization can be regarded as a coherent "intellectual tradition" in economic thought - that is, as a set of discourses involving distinct issues, methods, formalities, and vocabularies. I, therefore, understand the expression of "intellectual tradition" in the broad sense of what Antoine Missemer and François Allisson call "intellectual legacy," which includes not only ideas and concepts but also methods and epistemological perspectives (Allisson and Missemer 2020).

I analyze the historical development of non-proletarianization theory, focusing on the works of three authors: Khaim Dov Horovitz (1865-1933), who is usually regarded as having elaborated the first version of the theory in 1902 (Gutwein 1990; Mintz 1976, p.59), Yakov Leshchinsky (1876-1966), and Ber Borochov (1881-1917). These three figures diverged in important ways. Borochov even claimed that he had rejected the non-proletarianization thesis. Also, other important political protagonists of the period developed earlier or similar pessimistic conjectures about the future of Jewish workers. In 1893-1894, leaders of the Bund launched a new program of "agitation," based on the idea that the Jewish masses could develop class consciousness through participation in economic struggles, particularly strikes (Mendelsohn 1970; Frankel 1984). Opponents of this campaign argued that Jewish workers and their impoverished bosses were mostly engaged in craft production and, therefore, did not constitute a proletariat or a capitalist class in the Marxist sense. One of these opponents, Abraham Liessin, coined the famous phrase suggesting that Russian Jews' class struggle was a struggle "of the beggars against the paupers" (quoted in Peled 1989, p.80). The idea of nonproletarianization, thus, played a central role throughout the 1890 s in critiquing the leaders of what became the Bund in 1897; the doctrine was disseminated in different versions and formats. Hence, as Daniel Gutwein suggests, "it would be more accurate not to speak of a (single) theory, but rather of non-proletarianization theories" (Gutwein 1990, p.148).

If the early conjectures about Jewish non-proletarianization in the 1890s anticipated the theories of the next decade, the latter nonetheless marked a significant departure from the former, as I shall argue later-especially regarding their statistical content. I also chose to focus on Horovitz, Leshchinsky, and Borochov because these three authors shared some common features. First, they belonged to the same "generation of 1905" that sought to synthesize, at a young age, Jewish nationalism and socialism in Russia, and that was especially active from 1903 to 1917 (Trachtenberg 2008, p.40; Brym 1978). These three figures also shared similar intellectual backgrounds and formative experiences, especially in economics. As the bibliographical references in their works indicate, Borochov, Horovitz, and Leshchinsky were - of course - influenced by Marx, but also by economists of the German historical school in economics, as was the case for most Jewish statisticians and economists in contemporary Eastern Europe (Vallois 2021a). Horovitz, in particular, studied and defended a dissertation in economics and social science at the University of Berlin (Wininger 1928; Orechov 1957; Kleiman 1973). Leshchinsky also spent several semesters in the universities of Bern and Zürich (Estraikh 2007).

Another important characteristic of these three authors was their status as public figures

\footnotetext{
${ }^{4}$ This theory is also called "un-proletarianisation," "non-industrialization," or "abnormal proletarianization" theory (Peled 1989, p.80). To avoid any misunderstanding, I use only the term "non-proletarianization" in this article.
} 
and their ability to reach large audiences, at least among Jews. This ability was, of course, particularly true of Borochov since he was a major political figure and is usually remembered as the main founder and inspiration of Labor Zionism (Katz 2010). Horovitz and Leshchinsky came to be known to a large audience, too, through their activities as journalists. Under the pseudonym of "a soykher" (a merchant), Horovitz pioneered economic journalism in Hebrew and Yiddish in the early twentieth century. Throughout his long career, Leshchinsky regularly contributed to the main Jewish journals in Eastern Europe and the United States, addressing a large, worldwide readership (Manor 1961; Estraikh 2007).

Finally, Horovitz, Borochov, and Leshchinsky had no academic positions as economists or statisticians despite their extensive influence. Jews' very difficult access to Russian universities made their academic careers almost impossible. They worked as journalists, writers, or professional political activists. Also, they published mostly in Yiddish and Hebrew, and apart from Borochov's most famous texts, most of their works have not been translated. ${ }^{5}$ This factor explains why, to my knowledge, no research had been produced on their writings in the history of economic thought. The current article, therefore, fills an important gap in the existing literature. Historians of Russian economic thought have not yet produced any detailed analysis of the economic problems and ideas pertaining to Russian Jewry - even though these questions were crucial in Russia for both economists and political activists, and the Bund and Zionist Socialist movements were among Russia's largest mass-based worker organizations (Peled 1989, p.3).

In this paper, I discuss mostly economic issues. Therefore, my perspective differs from the very few works of Jewish history on this subject (Mintz 1976, p.59-63; Gutwein 1990, 1994; Frankel 1984; Guterman 1985; Peled 1989, p.73-92). These studies focus mostly on whether Borochov subscribed to this theory and examine Borochov's political motivations in light of the underlying political context and the conflicts within Labor Zionism, mostly in the first decade of the twentieth century. Relative to the existing literature, I do not provide a new perspective on Borochov's political motives. When offering some contextual explanations, I rely on secondary sources.

While I do not intend to underplay the role of political factors, my study aims to contribute to the literature by situating these theories in the larger development of economic ideas and doctrines, and by focusing on formal aspects that have largely been neglected. I argue first that a central aspect of these discourses about Jewish non-proletarianization was their strong statistical underpinnings. I insist that these doctrines depended upon major statistical developments in late nineteenth century Russia. This analysis thus requires that we extend our examination to before the existing literature on the topic, which focuses mostly on the 19021917 period. As a result, I examine a much longer historical period since I consider Leshchinsky's later works in the 1920s-1930s as a continuation of the same tradition.

Beyond Russia and Zionism, this article also discusses broader issues, addressing wider audiences among historians of economic thought. The non-proletarianization problem did not matter only to Russian Jews; it also played a very important role in contemporary debates surrounding the so-called sweating system. In the United States, the rise of "sweating" industries in the Progressive Era was firmly associated with Eastern European Jewish immigrants (Bender 2004, p.8). This association figures particularly prominently in the report that John R. Commons wrote for the Industrial Commission in 1901 (Commons 1901). The antisemitic nature of Commons's comments on Jewish garment-industry workers was recently debated in this journal (Fiorito and Orsi 2016; Chasse 2018). The current article offers a comparative perspective on this debate, including Jewish and non-Jewish voices. I suggest that

\footnotetext{
${ }^{5}$ Robert Brym recently translated into English Leshchinsky's The Jewish Worker in Russia (Leshchinsky [1906] 2018), The development of the Jewish People over the last 100 years (Leshchinsky [1928] 2020), and The Economic Situation of the Jews in Interwar Poland (Leshchinsky [1931] 2020).
} 
both non-proletarianization theories and the anti-sweatshop campaign targeted Jewish workers as "weak" proletarians, reactivating antisemitic tropes about Jews' bodies and morality. Yetunlike Commons-Horovitz, Borochov, and Leshchinsky eschewed the language of race and supported completely different policies, especially regarding Jewish immigration.

\section{STATISTICAL AND THEORETICAL KNOWLEDGE ABOUT JEWISH POVERTY IN EASTERN EUROPE BEFORE 1902}

Jewish workers' poverty in Russia was a well-documented phenomenon in the late nineteenth century. This section describes the empirical literature of the late nineteenth century, which the Labor Zionists of the early twentieth century both inherited and criticized in the 1900 s.

One of the earliest attempts to document the Russian Jewry's general economic condition came from the jurist Ilya G. Orshanski (1846-1875) in the 1870s. Orshanski wrote a series of articles about Jews' socio-economic status in Russia, from 1869 to 1871, in the Russian Jewish journal Den. These studies were then published in two volumes, entitled The Jews in Russia (1872) and Russian Legislation Affecting the Jews (1877). Orshanski's studies marked a breakthrough relative to the ideology of the Haskalah (the "Jewish Enlightenment"), an ideological movement promoted by (some) Jewish intellectuals in the eighteenth and nineteenth centuries. While previous Maskilim ("Enlightened Jews") considered socio-economic reforms in moral terms, urging Russian Jews to "modernize" themselves and abandon "obscurantist" religious practices, Orshanski aimed for an impartial and scientific analysis (Stern 2018, pp.6062). He accomplished an important work of compiling and synthesizing empirical material that had previously been collected, and indeed, he came to be praised in later empirical research for being the first to build his analysis "on figures and facts only" (JCA [1904] 1906, p.3). As a jurist, Orshanski described the juridical details of anti-Jewish discrimination in Russia, and also described this legislation's historical emergence.

Orshanski was a particularly important influence for Horovitz, who regularly quoted Orshanski's works (e.g., Horovitz 1902, p.66, p.122). After Orshanski, Jan Bloch's initiatives in the next decade aimed to collect statistical material more systematically. Bloch (1836-1902) was a rich Jewish financier and philanthropist. Though he converted to Protestantism in 1851, he remained concerned with Jews' situation in the Russian Empire. In the 1880s, he set up a statistical bureau to collect material about Jews' economic conditions in the Russian Pale of Settlement and in Poland. This material led Bloch to publish, in 1891, an 1,800-page book entitled A Comparison of the Physical Subsistence and Moral Condition of the Population in the Jewish Pale of Settlement and Elsewhere. Bloch's study was not widely disseminated. Shortly after publication, almost all copies were accidentally destroyed, and only 25 copies survived (Alroey 2006, p.267).

The research of Andrei P. Subotin (1852-1906) was much more influential. Subotin, who was not Jewish, worked for Bloch's statistical bureau. He traveled extensively in the Pale of Settlement in the 1880s to document Jewish poverty. In 1888 and 1890, Subotin published two volumes entitled In the Jewish Pale of Settlement, which appear to have been funded by Bloch (Alroey 2006, p.267). These studies were important references for the Labor Zionists in the 1900s. Horovitz, for instance, quotes extensive parts of "Professor Subotin's" works in his 1902 article (Horovitz 1902, pp.110-118). Subotin's studies were also regularly cited in Leshchinsky's writings (e.g., Leshchinsky 1931, p.85; 1960, p.41). Beyond statistical material per se, Subotin's methods in his detailed reports (e.g., descriptions of people's houses and transcripts of his conversations with residents) were particularly influential-especially for Leshchinsky (Alroey 2006, p.277). These reports paved the way for similar empirical surveys.

The next crucial step was the emergence of large-scale statistical knowledge about 
Eastern European Jews. This knowledge resulted from two important surveys that had started the same year, in 1897, and whose results became available during the first years of the next decade: ${ }^{6}$ the Russian census and the inquiry of the Jewish Colonization Association (JCA). As the chronology suggests, these two surveys directly influenced the discussions of Jewish nonproletarianization that started in 1902.

The 1897 Russian census brought two major innovations to the socio-economic knowledge of Jewish economic life in Eastern Europe. First, it employed large-scale resources, involving more than 150,000 census-takers (Cadiot 2004, p.442); therefore, it significantly expanded upon previous research, which had been restricted to specific towns or regions. One of the main advantages of the Russian census was that it was quasi-exhaustive - at least for Jews living in the Russian Empire. Though it might have been conceived as a tool for the regime's policy toward (and against) nationalities, paradoxically, the census ultimately made ethnic and national minorities more visible (Cadiot 2004). In the Jews' case, the census provided the first accurate estimate of the population, identifying Jews mostly on the basis of their mother tongue. Another important characteristic of the census was that it contained not only demographic material but also socio-economic data, notably on professions, occupations, literacy, and education (Cadiot 2004, p.442).

The JCA was established in 1891 by Baron Maurice de Hirsch, a rich philanthropist. Its main goal was to move a large number of impoverished Jews from Russia to agricultural colonies throughout the world (Norman 1985). In 1897, the JCA launched a large statistical inquiry into several governates of Imperial Russia. Though it did not exhaustively cover the Russian Jewish population, the survey involved a large-scale dimension, providing statistics about 1,302 towns with the help of more than 1,000 correspondents (JCA [1904] 1906, p.8). The study was a storehouse of socio-economic information - including, in particular, a detailed survey of Jewish handworkers, artisans, and small industry.

The JCA's survey was framed by a particular political agenda. It was motivated by the idea of "productivization"- that is, diverting the Jewish population to agricultural and industrial occupations, sectors that were regarded as "productive." As a result, the survey did not cover commerce, which was considered a non-productive sector, even though a large number of Jews had commercial occupations. These political and ideological motives also influenced the report's comments and interpretations. Indeed, the survey's authors expressed a clear vision of the causes underlying the perceived weakness among the Jewish working class. Repeatedly, these authors claimed that religious rules - observing the shabbat and eating kosher food, in particular - prevented Jews from working at Christian companies (JCA [1904] 1906, p.246, p.257-258; JCA 1908, p.16). As a result of this self-imposed isolation, the survey suggested, Jewish artisans received poor technical training and produced low-quality goods.

The blame for this "professional mediocrity" (JCA [1904] 1906, p.270) was not entirely placed on Jews themselves; the report insisted on the Pale of Settlement's negative influence, which prevented Jews from living and working in the richest and most developed part of Russia. Yet, ultimately, the report's authors considered-consistently with the socio-economic ideology of "productivization" in the Haskalah - that Jewish workers and the Jewish working poor were too weak to help themselves and should be led by "Israelite notables" and "enlightened" leaders (p.270).

\footnotetext{
${ }^{6}$ The publication of the Russian census results started in 1898 and finished in 1905 (Cadiot 2005, p.449). The first part of the JCA's study was published first in Russian in 1904 and then in French two years later; the second part came out in 1908. Yet the results of the JCA's survey seem to have been available before 1904, and they probably circulated informally. For instance, Horovitz thanks a "Doctor Linder" for having provided him JCA data in one of his 1902 articles (Horovitz 1902, p.61).

${ }^{7}$ On the debate over Jewish productivization, see Karp (2008).
} 


\section{HOROWITZ AND THE BIRTH OF NON-PROLETARIANIZATION THEORY}

In 1902, Horovitz published a series of seven articles in Hebrew entitled "The Economic Question and Its Place in Our National Movement" in the journal Ha-Shiloakh (Horovitz 1902ab-c-d-e-f-g). That same year, Horovitz presented his study at the Second Conference of Russian Zionists in Minsk. This conference stemmed directly from internal struggles within the Jewish labor movement. The year before, the Bund had expelled its Zionist members after its Fourth Congress. The Minsk conference presented an occasion to gather dissident Bundists (Peled 1989, p.79). Horovitz thus addressed an audience that mostly comprised opponents to the Bund's new anti-Zionist orientation, and his lecture significantly influenced the Labor Zionist movement (Peled 1989, p.79; Gutwein 1994, p.113; Mintz 1976, p.59).

In "The Economic Question," Horovitz claimed that fighting Jewish poverty required quantitative knowledge:

There is no need to demonstrate that Israel is a poor and miserable Nation. [...] But we need [...] to know the measure of our poverty, its particular form and its particular causes, so that we can fight against it and improve our terrible economic situation. As a result, we have to observe the economic life of the Jews, their different occupations - their source of subsistence (makorei mikhyatem) or, more accurately, their source of poverty (makorei aniutem) (Horovitz 1902d, p.60).

Statistics were thus needed, according to Horovitz, as both descriptive (i.e., to describe, observe, and understand causes) and normative tools (i.e., to fight poverty and improve the economic situation of the Jews). The study was structured per this agenda. The descriptive parts were relatively short and occupied the fourth and fifth articles only. Horovitz based his descriptions on only a few statistical sources: the JCA's survey, a few public and official economic statistics, and some materials from the ORT. ${ }^{8}$ His analysis did not address the entire Jewish Pale, and it was restricted only to several governorates that he considered representative (Horovitz 1902d, p.60).

Horovitz's basic observation was that Jews tended to be concentrated in the lowest-paid, skilled, and technologically advanced economic sectors. Roughly half of the Jewish population was employed in handicrafts, a third in commerce, and only a tenth in industry-with minor fluctuations between governorates. Jews' involvement in industry was significantly lower than Christians'. Analyzing volumes of businesses and numbers of employees, Horovitz also observed that the tiny Jewish industry was actually "almost similar to handicraft" and pointed out its "sad situation" (Horovitz 1902d, p.66). A classification of craft branches according to their annual average earnings showed that Jews were even more active in a given branch of production if its revenue was low (relative to other branches) (Horovitz 1902d, p.68). Horovitz thus concluded that Jews suffered generally from the process that Gutwein calls "vertical dispossession" (Gutwein 1990, 1994): industrial developments had degraded Jews' economic situation, causing a gradual transition from the highest sectors (i.e., industry and productive crafts) to the lowest sectors (petty trade and domestic work) until Jews had become completely "superfluous" (Horovitz 1902e, p.114).

Horovitz supplemented factual observations with his own explanations, mainly in his fifth and sixth articles. Horovitz regarded the main cause of Jewish "non-proletarianization" as a lack of territorial autonomy and the "national struggle." As a national minority without a

\footnotetext{
${ }^{8}$ The ORT was an organization that sought to promote occupational change for Jews in the Russian Empire. "ORT" is the Russian initialism for the "Society for Handicraft and Agricultural Work among the Jews of Russia."
} 
territory, Jews suffered from increasing competition from both national workers and capitalists (Horovitz 1902e, pp.118-123). For instance, trade unions in Western Europe were naturally inclined to organize themselves on a national basis in order to promote the welfare of the national proletariat and thus prevent foreign workers from accessing the labor market (Horovitz 1902e, p.126).

Horovitz's focus on (this lack of) territorial autonomy reflects his political and polemical motives. If the "economic question" was, above all, a national concern (Horovitz 1902a, p.18), socio-economic policies without national or "spiritual" goals were bound to fail unless Jews' "national existence" was itself reformed. This claim was polemically intended to oppose both the Bund and other non-Zionist agendas of Jewish "productivization," as embodied by the JCA's report. Horovitz did not view the source of Jews' economic problems as their observance of strict religious rules or their inability to assimilate or adapt to modern economic life, as the authors of the JCA report had claimed. On the contrary, he promoted a reinvigorated "national spirit," which he felt was necessary for Jews to compete successfully in the national struggle. This view led Horovitz to downplay the role of legal discrimination, which the JCA survey had regarded as a major source of Jewish poverty (Horovitz 1902e, p.125). Horovitz's claim that the Russian regime did not produce a "significant impediment" (Horovitz 1902e, p.110) to Jewish economic activities might seem surprising, given the overwhelming evidence of this discrimination's significance; yet it can be easily explained by his ideological motives. Ultimately, considering the economic question as a national matter meant that the only remedy to Jewish economic problems was Jews' departure from Russia.

Horovitz's study also opposed the usual rhetoric of Maskilim and Western European philanthropists, who argued that Jews should receive help "from the outside." This belief, Horovitz claimed, fundamentally opposed "the fundaments of Marx's and Engels' theory" and neglected the fact that "simple and naïve men [...] can easily understand high and important ideas." In reaction to the anti-religious polemics of the "enlightened," Horovitz even wrote that this taste for intellectual discussion of social problems was "actually reinforced by religious feelings of the masses" (Horovitz 1902a, p.17). Hence, Horovitz strongly defended the principle of self-organization: associations of Jewish workers, which were required to compete in the national struggle, "shall be created only if workers are actively involved in their foundation [...]. Self-help is the foundational principle of any economic ethic" (Horovitz 1902g, p.405).

By claiming that Jewish economic and national questions were aspects of the same problems, Horovitz also meant to challenge what he called "cultural Zionism." From Horovitz's perspective, cultural or political Zionists - such as Theodore Herzl and his followers-were concerned only with political, and mostly diplomatic, issues. He felt that they had failed to understand that Eastern European Jews' terrible economic situation prevented a national aspiration among most of the world's Jewish population, notably in Galicia (Horovitz 1902a, pp.18-19). Zionism required a social and economic improvement of Jewish economic life "here and now," in the Diaspora, through such concrete actions as the establishment of Jewish cooperatives, professional education, or emigration to "the Land of our Fathers" (Horovitz 1902f, p.332). As has been said, Horovitz regarded these reforms as insufficient; yet they were necessary for the Jewish people's preparation for economic and national "resurrection" (Horovitz 1902f, p.333).

Horovitz's essay thus allowed for political pragmatism. If territorial autonomy remained his long-term goal, Horovitz's agenda also intended to address present socio-economic issues. His goals were actually compatible with many reforms later promoted by Labor Zionists' various initiatives. In this regard, a particularly pressing issue was Jewish immigration from Russia, which was reaching its peak in the first decade of the twentieth century. Horovitz lamented Jewish immigrants' disproportionate concentration in the "sweating system," notably in England (Horovitz 1902e, p.125). He called for organized migration, similar to Borochov 
and Leshchinsky's later proposals.

Alongside his political and polemical aims, theoretically, Horovitz's proud support of Eastern European Jewish nationalism was very much influenced by the folk psychology that he had inherited from German historicism. ${ }^{9}$ This folk-psychological frame led to an ambivalent attitude toward Jewish workers. On the one hand, according to Horovitz, Jews were not directly responsible for their situation, which had resulted from a lack of territorial autonomy. He also praised Jews' perseverance as a nation despite persecutions and economic hardships (Horovitz 1902f, p.329). Intense Jewish religiosity attested to the vitality of "the spiritual life of the Jews": "in their shabbat, are effective and visible the positive characteristics of the Jewish spirit." On the other hand, Horovitz regretted Jews' "double-faced nature"; their practical life, as opposed to their spiritual life, was only governed by "self-love and restricted individual interests" (Horovitz 1902g, p.401). Their feeling of unity remained "religious-national," failing to translate into economic and social terms (Horovitz 1902f, p.333). According to Horovitz, the excessive individualism underpinning Jews' economic behavior explained the lack of "mutual economic institutions," labor organizations, and unions among Jewish workers (Horovitz 1902f, p.333).

In drawing this Janus-faced portrait of the Jewish economic agent, Horovitz invoked many economic stereotypes about Jews that were prevalent in late-nineteenth-century German folk psychology. ${ }^{10}$ He particularly defended the idea that Jewish existence had always depended on external circumstances and, therefore, that Jews tended to wait for "economic miracles." For Horovitz, this perspective explained Jews' professional instability and the predominance of their "commercial spirit" that naturally inclined them toward speculation, rather than production (Horovitz 1902e, p.123).

This portrait clearly channeled antisemitic tropes about Jews' alleged economic selfishness - or their inclination for speculation and commerce. Importantly, though, from Horovitz's perspective, these negative characteristics did not reflect "intrinsic" or "essential" features of Jewish workers; rather, they were dictated by Jewish workers' lack of territorial autonomy. According to Horovitz, Jews were determined to have "wandering" occupations with "changing conditions" because they lacked a "solid economic ground"- that is, an autonomous territory (Horovitz 1902e, p.122).

In this regard, Horovitz's portrait of the Jewish worker was very likely inspired by the image of the "Luftmentsch" that had been popularized by Zionist leader Max Nordau in his discourse at the 1901 Fifth Zionist Congress in Basel. In this speech, Nordau used the word "Luftmentsch"- literally an "air-person" or "air-man" - to refer to Eastern European Jewish peddlers, petty traders, or paupers without a definite occupation or business. He described these characters waking "up each morning with the hope of some miracle coming to pass that would furnish them some way to get through the day." Thus, like Horovitz, Nordau associated professional instability with dependence upon a "miracle," suggesting that these characters stemmed from "groundlessness" (Bodenlosigkeit) - that is, the lack of Jews' own territory. Luftmentschen, he said, "lack a solid economic base to stand upon and they live [...] day by day, by grace of miracles rather than proper labor" (Nordau [1909] 1923, pp.118-119) ${ }^{11}$.

\footnotetext{
${ }^{9}$ In one of his previous articles, Horovitz provided an account of Jewish economic history that was very much inspired by Wilhelm Roscher (Horovitz 1900). In his 1902 essays, Horovitz also quoted Gustav Schmoller (Horovitz 1902a, p.24), Adolph Wagner (Horovitz 1902c, p.305), and Johannes Conrad (Horovitz 1902a, p.21). On the influence of Roscher on Horovitz, see Gutwein 1994.

${ }^{10}$ For an analysis of these stereotypes, see Vallois (2021b).

11 This quote was taken from an original copy of the discourse in German, but I borrowed its English translation from Lederhendler 2009, p.133. On the figure of the Luftmentsch, see Berg 2008, Vallois and Imhoff 2020.
} 


\section{IV. “WHAT DO YOU SAY ABOUT HOROVITZ'S NUMBERS?" LESHCHINSKY'S STRONG PESSIMISM AND BOROCHOV'S CRITIQUE}

Horovitz's study sparked confusion among left-wing Russian Zionists. After the Minsk conference, the pro-Palestine wing of the Zionist movement in Russia led a campaign of "agitation" to spread its Palestine-oriented program among youths and workers (Frankel 1984, pp.336-337). Yet the Russian context raised major doubts about the program's feasibility. For instance, a few weeks after Horovitz's lecture, Yosef Leshchinsky-Yakov's brother-wrote a letter to Dov-Ber Slutski, a long-time friend. He explained that he was willing to participate in the "agitation" in Palestine's favor but confessed to having no "definitive idea about Zionism." Jewish workers' desperate economic situation in Russia necessitated deeper theoretical reflections. Yosef Leshchinsky wrote, "Theory stands in our way [...]. What do you say about Horovitz's numbers?"12

In 1903, these doubts crystallized into a dissident political movement. That year, the pogrom in Kishinev and the threat of further massacres made an enormous impression on many Labor Zionists, including Borochov (Frankel 1984, p.335) and Yakov Leshchinsky (Manor 1961, pp.31-34). At the 1903 Sixth Zionist Congress in Basel, Theodore Herzl proposed the so-called "Uganda plan" to create a Jewish territory in British-controlled Uganda (now in Kenya). The proposal split the Zionist movement between the faction who still preferred the idea of emigration to Palestine and the "territorialist" faction, which was "prepared to sacrifice the "Land of Israel"' in favor of another territory (Alroey 2011, p.9). Territorialists felt that an immediate relief of Jews' distress in Russia required a rapid response; they could not wait on the creation of a Jewish state in Palestine.

This sense of urgency clearly motivated Leshchinsky's pessimistic perspective on the non-proletarianization problem. It felt all the more compelling in 1906, when another wave of pogroms swept through Russia in the revolution's aftermath. In this context, non-proletarization theory became a theoretical justification for territorialism. Because of Jewish workers' "abnormal" situation, Leshchinsky and his followers argued, Zionism could not develop; thus, immediate political action was needed (Gutwein 1990, pp.170-172). The Zionist Socialist party, created in 1906, was built upon this political platform, including support for any territorial solution, as well as active involvement in the political struggle to overthrow the Tsarist regime (Mintz 2010).

Thus, in the second part of the 1910s, non-proletarization theories reflected a particular political context that had not previously existed. Before 1903, no debate had questioned "territorialism." Many Zionists, including Horovitz, had not felt any contradiction between Zionism and their willingness to establish a national territory for Jews outside of Palestine. Yet, from a theoretical perspective, Leshchinsky's 1903-1907 writings extended Horovitz's articles published in 1902. Before 1903, Leshchinsky had been working on his first essay, which was published a year after Horovitz's articles on "The Economic Question" in the same journal, $\mathrm{Ha}$ Shiloakh (Leshchinsky [1903] 1960). In this empirical study entitled "Statistics of a Small Town," Leshchinsky gathered socio-economic statistics about the Jewish population of his hometown, Horodyshche (now in Ukraine). He reached similar conclusions as Horovitz: most Jewish workers in Horodyshche belonged to a middle class of petty traders and artisans, yet the vast majority were losing their sources of income. Describing their misery, in this early study, Leshchinsky discussed a process of "proletarianization" (hitproletariut) (Leshchinsky [1903] 1960, p.25). This process did not mean Jewish workers were becoming proletarians in largescale industry; rather, they tended to concentrate in sweatshops (shitah ha-ezah) and home industry — that is, in the lowest branches of industrial production (Leshchinsky [1903] 1960,

\footnotetext{
${ }^{12}$ Yosef Leshchinsky to Dov-Ber Slutski, 5 November 1902. YIVO Archive. Papers of Jacob Leshchinsky, RG 339, Folder 11.
} 
In 1906, Leshchinsky published an essay entitled The Jewish Worker in Russia. This pamphlet became an ideological cornerstone of the Zionist Socialist party ${ }^{13}$ (Manor 1961, pp.74-75; Mahler 1967, p.89). Yet The Jewish Worker in Russia reads less as a political manifesto than as an economic-statistical inquiry, similar to Horovitz's. Building on recent developments in statistical knowledge, Leshchinsky generalized his first study's results. He evidenced what he now referred to as "non-proletarianization" (nitproletarizirung). ${ }^{14}$ Using statistics from the 1897 Russian census, he estimated that non-Jewish Russian workers were employed as factory workers more than four times as often as Jews (Leshchinsky 1906, pp.18$20)$. With this estimate, Leshchinsky meant to debunk a Bundist brochure's claim that Jews and non-Jews were similarly represented among industrial proletarians. ${ }^{15}$

Data from the JCA's survey also indicated that Jewish-owned factories were smaller, that they used less machine power, and that Jewish labor was almost completely employed in manufacturing (Leshchinsky 1906, pp.36-37). Consistent with Horovitz's theory, Leshchinsky observed that "the closer one approaches the most developed branches of production (e.g., steel, chemical industries, mining) the smaller the proportion of Jews in them" and that Jews were stuck in "the backward branches of production," such as the food and garment industries (Leshchinsky 1906, p.24).

Leshchinsky's explanation also resembled Horovitz's: the main reason for Jewish "nonproletarianization" was the "national struggle" between Jewish and Christian workers in Russia. Christian factory-owners refused to hire Jewish labor in order to "paint" class antagonism with "national colors" and "to manipulate (non-Jewish) workers lacking class consciousness" (Leshchinsky 1906, p.93).

Yet Leshchinsky's prognosis was much more pessimistic than Horovitz's. While Horovitz had considered non-proletarianization to affect the Jewish middle class as a whole, and that it could help raise this group's class and national consciousness, Leshchinsky suggested that a differentiation process among Jews prevented any possibility of social progress (Gutwein 1990). On the one hand, "the real economic interests of the Jewish bourgeoisie demand that it assimilates with the (Russian) bourgeoisie [...] to demonstrate its [...] loyalty to the country"; therefore, Jewish capitalists refused to hire Jews in their factories (Leshchinsky 1906, p.103). On the other hand, the Jewish proletariat was a "lumpenproletariat" (Leshchinsky 1906, p.5), "utterly disorganized, helpless," and did "not constitute a political force"-unlike the "modern" proletariat in Western Europe, particularly in England (Leshchinsky 1906, p.10).

For Leshchinsky, Jews' massive emigration was one of the clearest symptoms of Jewish working-class weakness. This migration was bound to fail, as Leshchinsky argued in his pamphlet The Jewish Worker in London, which came out a year later, in 1907. ${ }^{16}$ Using figures and reports from various sources, including Charles Booth (Leshchinsky 1907, p.10) and Beatrice Webb (Leshchinsky 1907, p.17), Leshchinsky observed that Jewish immigrants in London tended to concentrate in the economic branches where the "shivts-sistem"- that is, sweatshops and home industry-predominated.

Jewish workers' disproportionate concentration in the shvits-sistem was a decisive issue for Leshchinsky because it revealed, from his perspective, a fundamental "psychological" maladaptation to modern economic life among Jewish workers. Working at home or in a

\footnotetext{
${ }^{13}$ The essay was also published in a reduced form in Der nayer veg, the organ of the Socialist Zionist Party (Guterman 1985, pp.43-44).

${ }^{14}$ Though this passage marks the first occurrence of the expression "non-proletarianization" in this corpus, it does not necessarily mean that Leshchinsky invented the term. As we have seen, the term was in common usage at the time and was used, for instance, by Shmuel Charney in an essay published that same year (Charney 1906). ${ }^{15}$ This brochure was written by Shmul Gozhansky (1903).

${ }^{16}$ An earlier version of this essay was published in 1904 in the review Yiddishe Bibliotek (Estraikh 2007, p.218)
} 
sweatshop prevented the Jewish proletariat's concentration, hindering its class consciousnesshence the lack of proletarian organizations and the influence of "anarchism" (i.e., individualistic and non-structured utopias) among London's Jewish working class (Leshchinsky 1907, pp.28$31)$.

Leshchinsky also suggested that this particular character of the Jewish worker both resulted from and caused economic dire straits. In a later article entitled "The Psychology of Jewish Migrants," published in a German statistical journal in 1913, Leshchinsky developed a general theory about Jewish migrants' capacities that explained why Jews around the world were excessively concentrated in the less-technologically-advanced economic branches:

The Jewish petty traders and commercial intermediaries [...], who form the vast majority of Jewish emigrants [...] are used to rely more on their intellectual agility than on their muscular force. When they arrive in a country where their agility and experience cannot be used, they are powerless and helpless [...]. [The Jewish immigrant worker] has not been trained to skilled work, he is not capable of basic physical work, he does not know discipline, and it is very difficult for him to get used to the situation of dependency and inferiority of workers [...]. Home-industry is therefore the most adapted for the Jewish immigrant (Leshchinsky 1913, pp.78-79).

Later, Leshchinsky elaborated on this description. He contrasted non-Jewish peasants with Jewish petit bourgeois, writing that "the rural non-Jewish peasant with his healthy body and primitive mentality, trifling needs and even more trifling ambitions [...] was much less expensive and easier to employ than the small-town petit bourgeois Jew with his weak body, excitability, higher standard of living and more developed mind" (Leshchinsky 1931, 71). ${ }^{17}$ This psychological portrait of Jewish and non-Jewish workers recurred throughout Leshchinsky's works (e.g., Leshchinsky 1916, p.165; [1933] 1947, p.201).

Leshchinsky's strong pessimism was severely criticized by Borochov. Unlike Leshchinsky, Borochov did not support territorialism. Therefore, he rejected the political doctrine of the Zionist Socialist Party. Since 1904, Borochov had been working as an "agitator" for the Zionist movement's pro-Palestine wing in Russia (Frankel 1984, pp.331-332). He remained committed to the Palestine cause throughout his career. In 1906-1907, he defended the idea that Jews' participation in Russia's class struggle would spontaneously lead to emigration to Palestine. From there, he argued, the concentration and development of the Jewish proletariat would begin.

Importantly, though, from Borochov's perspective, Palestine offered no specific cultural or emotional appeal to Jews; it offered strictly economic advantages. ${ }^{18}$ As for Borochov, any Jewish settlement outside Palestine was bound to fail because Jewish workers could not compete with native peasants for physical jobs, thus undermining the formation of the Jewish proletariat. Only Palestine's native population was culturally closer to Jews and, therefore, could be gradually absorbed into the growing proletariat.

Borochov thus criticized non-proletarization theories inasmuch as they politically justified territorialism. He specifically rejected the idea that Jewish workers lacked class consciousness, which contradicted his own hypothesis that the Jewish proletariat could grow spontaneously. In 1906, when the Zionist Socialist Party published Leshchinsky's The Jewish Worker in Russia, Borochov wrote Our Platform, which became the political manifesto for the rival Poale Zion party. In Our Platform, Borochov did not directly criticize non-

\footnotetext{
${ }^{17}$ The quote was taken from the original version in Yiddish, but I borrowed its English translation from Robert Brym (Leshchinsky [1931] 2020, p.65).

${ }^{18}$ On Borochov's economic justification for Palestine, see Frankel 1984, pp.340-342.
} 
proletarianization theory, but he opposed Leshchinsky's theory by pointing out that the Jewish proletariat was "already class-conscious" and had "an overwhelming revolutionary energy" (Borochov [1906] 1984, p.90).

A year later, Borochov explicitly criticized what he referred to as theories of "nonindustrialization." Again, his critique was fundamentally political. Claiming that Jews are not "bearers of the socialist movement" was politically counterproductive because it hindered Jews' desire to heal from this "sickness of non-industrialization" (Borochov [1907] 1984, pp.31-32). Borochov accused Sejmists and Zionist Socialists of distrusting the Jewish proletariat's revolutionary capacities and of relying on the bourgeoisie as a political avant-garde.

Borochov strove to empirically support his objection to non-proletarianization theory. If Jewish workers were observed to be politically active, he suggested, then they could be regarded as true proletarians (Borochov [1907] 1984, p.32). In a later essay entitled The Jewish Worker Movement in Figures, published in 1916 but originally directed against Leshchinsky (Gutwein 1990, p.180), Borochov tried to substantiate this empirical refutation. Using statistics from workers' organizations and unions throughout Europe, he showed that the Jewish proletariat was significantly more active and successful in strikes than other national workforces. If Jewish workers were less employed in large-scale factories compared to other workforces, they nonetheless benefited from their more urban character, which favored solidarity among Jewish workers - even in small-scale craft production. Hence, "the major characteristic of the Jewish economy," wrote Borochov, was not "the famous and meaningless non-proletarianization"; rather, "Jewish masses are proletarianizing" (Borochov [1916] 1923).

In The Economic Evolution of the Jewish People, published in 1916, Borochov retrospectively critiqued the non-proletarianization theories that had been popular among Labor Zionists in the 1900s. "Thirteen or fourteen years ago," recalled Borochov, "the so-called "nonproletarianization theory' (nit-proletarizirung-teorie) was fashionable among Jewish Socialists." Borochov credited Horovitz as "the first creator" of that theory, while he described Leshchinsky as the "most profound social economist from the Zionist Socialists," whose book The Jewish Worker in Russia offered the strongest theoretical support for this theory. Borochov repeated a previous argument that suggesting "the Jewish proletarian can not proletarianize" was self-contradictory; rather, empirical observation suggested that the Jewish masses "are proletarianizing and industrializing" (Borochov [1916] 1919, pp.2-3). ${ }^{19}$

As Gutwein argues, Borochov merely refused the political consequences of the nonproletarianization theory while agreeing with Leshchinsky and Horovitz on its "descriptive part"- that is, on the observation that Jewish workers were relegated to "lower" economic sectors (Gutwein 1990). According to Mintz, Borochov-like many Labor Zionists - actually subscribed to the thesis of non-proletarianization in the early 1900s, and his opposition at the end of the decade was guided by polemical motives against the Zionist Socialist party and particularly against Leshchinsky (Mintz 1976, pp.59-63). ${ }^{20}$

Indeed, Borochov admitted to some "sane truth" in non-proletarianization theory. In the remainder of his essay on The Economic Evolution of the Jewish People, after a short critique of the non-proletarianization theoreticians, Borochov empirically described the Jewish workforce. Ultimately, his description resembled Horovitz and Leshchinsky's views. Borrowing statistics from the 1897 Russian census, Borochov classified the Jewish employment

\footnotetext{
${ }^{19}$ The idea that "unproletarianization of the Jewish worker" was self-contradictory can also be found in Charney's article entitled "What Is the Jewish Worker?" (Charney 1906, pp.20-21), which was widely distributed at the time (Trachtenberg 2008, pp.87-88) and which very likely influenced Borochov and Leshchinsky (Gutwein 1990, p.169).

${ }^{20}$ In the 1910s, Borochov once again changed his views. Against the "economic determinism" and the thesis of a spontaneous development of the Jewish proletariat that he himself had defended, he now stressed the idea that Palestine had an emotional, "non-economic" appeal for Jews (Frankel 1984, pp.351-352).
} 
profile into five branches, depending on their degree of proximity to nature, from agriculture and manufacture to industries serving consumers directly. He observed that Jews were disproportionately concentrated in the consumer-serving sector, highlighting "the economic groundlessness of the Jews" and "the dominant law of Jewish economics, namely, that the concentration of Jewish labor in any occupation varies directly with the remoteness of that occupation from nature" (Borochov [1916] 1919, p.13). This Borochovian scheme of an "inverted" occupational pyramid popularized an idea that was close to the idea of vertical dispossession. This diagnosis, like Leshchinsky's and Horovitz's, entailed some pessimism about Jewish economic "relegation" in modern times since "obviously," Borochov wrote, "the fate of society does not on any extent rest on the needle or tobaccos industries" (Borochov [1916] 1919, p.13).

From the internal perspective of discourse and theories, and consistent with my interpretation, Borochov shared many common ideas and characteristics with Leshchinsky and Horovitz. As we saw earlier, discourses about Jewish non-proletarianization were largely based on statistical materials, and they benefited from the publication of a large-scale census about the Russian Jewry. As a result, the discussion about Jewish non-proletarianization was framed as a statistical debate from its very beginning. Numbers played a central role in the opposition between the Bund and Zionist Socialists, notably in Gozhansky's Bundist brochure mentioned above and its critique by Leshchinsky (cf. supra, Leshchinsky 1906, pp.17-20). ${ }^{21}$ Internal controversies among Labor Zionists were also framed by statistics. Borochov, for instance, strove to structure his opposition to Leshchinsky on numbers in The Jewish Worker Movement in Figures. In The Economic Evolution of the Jewish People, Borochov also criticized Leshchinsky for claiming - on the basis of the JCA's survey - that no factory in Russia employed more than a thousand Jewish workers in Russia despite this source indicating that a tobacco factory in Grodno employed 1,594 Jews (Borochov [1916] 1919, p.4). ${ }^{22}$

Horovitz, Leshchinsky, and Borochov also similarly explained Jews' relatively minimal participation in large-scale industrial work. They agreed that the main cause was "national struggle" - that is, competition between national groups. From a practical perspective, the three authors proposed similar "therapeutics" for what they perceived as Jewish workers" "social disease." Agreeing about the Jewish proletariat's "anormal situation," they called for economic reforms in the Diaspora "here and now." Borochov and Leshchinsky particularly agreed that the Jewish proletariat had to participate in Russia's class struggle and fight for any improvements.

In the very short term, Horovitz, Borochov, and Leshchinsky disagreed about some of these reforms. Borochov criticized Horovitz's project of cooperatives (Gutwein 1990, p.175), while his party adopted the Sejmists' demand for a Sejm, a Jewish national assembly. This demand was probably motivated by party interests and the need to distinguish the Poale Zion from the rival Zionist Socialist Party (Frankel 1984, p.348). Yet, as we shall see later, most of the opposition between the two parties faded in the interwar period. Moreover, former members of the two factions often collaborated in practical works. This cooperation was not mere political opportunism. Both Poale Zion and Zionist Socialists fundamentally agreed that

\footnotetext{
${ }^{21}$ In this brochure, which was directed against "Zionists" and "their lamentations about the anormal economic state" of the Jewish proletariat (Gozhansky 1903, p.6), Gozhanksy borrowed statistics from the JCA survey and tried to establish that the proportion of workers in the population was similar or even higher by the Jews than in the rest of the Russian population. Leshchinsky rejected Gozhansky's estimations.

22 Borochov was right. This claim can indeed be found in Leshchinsky's The Jewish Worker in Russia (1906, p.17), and the JCA's report mentions the same figure about the number of Jewish workers in tobacco manufacturing in Grodno (JCA 1908, p.81).
} 
political advances in Russia were only superficial and could not alter the Jewish working class's underlying economic structure.

Both the diagnosis and proposed cure for the non-proletarianization problem were also directed against similar non-Zionist targets, philanthropists, and Bundists in particular. Leshchinsky, for instance, stressed that Jewish artisans should "take charge of their self-help, organize themselves" because no lasting improvement could be expected from the occasional and accidental "good deeds" of Jewish philanthropists and the Jewish bourgeoisie (Leshchinsky 1912a, p.4). Meanwhile, he also rejected the Bundist idea that the dissolution of the Pale would help reduce Jewish poverty (Leshchinsky 1912c, p.25). More generally, emphasizing national struggle undermined the role of Jewish religious practices, which previous social reformers had usually identified - notably in the JCA's report and also among Bundist leaders (Peled 1989, p.75) - as major factors of Jewish poverty. In thus undermining the religious role, nonproletarianization theoreticians reacted to what they perceived as unfair attacks on religion and the Jewish masses' popular religious beliefs while also praising their cultural worth. Those who blamed Jews for the economic consequences of their shabbat, wrote Borochov, "do not understand that keeping shabbat is not only a religious rule, but a deeply enrooted custom from economic and social life; hence, it is an advantage and not a default of (Jewish) workers." In any case, most Jews were willing to work on shabbat, but this willingness did not help them get jobs (Borochov [ND] 1928, pp.180-181).

Like many of the period's Jewish radicals, Borochov, Leshchinsky, and Borochov thus expressed similar rejections of the Haskalah. Because it had opposed Jewish nationalism since its Fourth Congress in 1901, the Bund was associated with these liberal efforts to "modernize" Jews and to integrate them into Russian society (Trachtenberg 2008, p.39); therefore, it was rejected as a "socialist version of Haskalah" (cf. Peled 1989, p.69). ${ }^{23}$

A final and important aspect of this intellectual tradition was its methodological reliance on folk psychology alongside statistics and empirical material. I previously discussed Leshchinsky and Horovitz's arguments about Jewish workers' character. Similarly, Borochov proposed moral portraits, such as the following excerpt:

A Jew, possessing meager means, often decides to become a boss "on his own" [...]. The Jew possesses a stronger entrepreneurial spirit. He refuses to remain a proletarian [...]. This desire to achieve "success" is a deeply ingrained characteristic of the Jewish laboring masses [...] and furnishes the explanation for the instability of the Jewish laboring masses (Borochov, [1916] 1919, p.5).

Elaborating on this idea of a Jewish "entrepreneurial spirit," Leshchinsky wrote that given their "psychic liveliness," Jews strive "to free himself as quickly as possible from the worker's yoke and become an owner" (Leshchinsky 1931, p.71). Conversely, Borochov agreed with Leshchinsky about "the Jewish worker's inability to face competition of the non-Jewish worker" (Borochov [1906] 1984, p.81). He similarly contrasted non-Jewish peasants as "stronger physically, and their standard of living is lower," with "the Jewish worker" who "requires much more comfort and luxury; therefore he adapts himself more quickly to the class conflict and enters the struggle with his employer more readily" (Borochov [1906] 1984, p.81). Weak bodies, agitated minds, excessive individualism, and a desire to achieve "success" emerged as a similar picture of the Jewish worker across Horovitz, Borochov, and Leshchinsky's writing. ${ }^{24}$

\footnotetext{
${ }^{23}$ Note, though, that Horovitz did not nominally challenge Bundists in his 1902 study.

${ }^{24}$ Horovitz did not explicitly mention physical weakness in his essay, though it can be related to his belief that Jews are disproportionately involved in "spiritual life" and neglect practical and material activities (cf. supra).
} 


\section{NON-PROLETARIANIZATION, ANTISEMITISM, AND THE ANTI- SWEATSHOP CAMPAIGN}

An important corollary of the non-proletarianization doctrine was that Jewish migration could not succeed without territorial concentration. According to this theory, the fundamental cause of Jewish non-proletarianization was a lack of territorial autonomy. Therefore, Jewish workers' immigration outside of the Russian Empire simply meant moving the problem from one country to another. Horovitz, Borochov, and Leshchinsky all regarded Jewish immigrants' disproportionate concentration in what they called the "sweating system" as both a prediction and a confirmation of their theories. This perspective reflected a growing, wider concern about the so-called sweatshop in Western Europe and the United States. The phrase "sweatshop" was coined in the 1890s by US politicians, journalists, and economists to describe small shops of immigrant contractors (Bender 2004, p.9). Labor Zionists did not use this word, instead favoring the expression "sweating system" (shitah ha-ezah in Hebrew; shvits-sistem in Yiddish). Yet the terms carried the same meaning, contrasting with an idealized image of the "industrial factory" (Bender 2004, p.9). Sweatshops, or the sweating system, referred to the most "backward," non-mechanical, "light" industries that were concentrated in the "final levels of production" (e.g., Borochov 1906, p.84). This system was also characterized by extremely poor and unregulated working conditions and a "contracting system" in which intermediaries or "contractors" operated between capitalists and workers, further reducing their respective margins and wages (de Lagerie 2013).

Jews played a central role in the social and political discourse against sweatshops. Particularly in England and the United States, the sweating system's rise in the Progressive Era was firmly associated with Eastern European Jewish immigrants. Social reformers tended to blame Jews for the sweatshop's social problems (Bender 2004). An important primary source in this regard is the report on "Immigration and Its Economic Effects" that John R. Commons wrote for the US Industrial Commission in 1901 (Commons 1901). The antisemitic character of Commons's comments on Jewish garment workers in this report was recently debated in this journal (Fiorito and Orsi 2016; Chasse 2018). In the remainder of the current section, I do not exhaustively discuss Commons's alleged antisemitism. ${ }^{25}$ I merely invoke a comparative perspective on his report to draw a few general principles regarding antisemitism in the history of economic thought.

The following three excerpts from Commons's report represent the material at stake in the controversy between, on the one hand, Luca Fiorito and Cosma Orsi and, on the other hand, Dennis Chasse:

[The Jew's] physical strength does not fit him for manual labor. His instincts lend him to speculation and trade. His individualism unsuits him for the life of a wage-earner, and especially for the discipline of a labor organization (p.325).

Probably the Jewish immigrant changes his standard of living soonest. When the Jew wants to make more money, he will leave his former occupation as operator or baster, etc., and will become a contractor or storekeeper. So that instead of trying to raise the standard of living in the trade, he will try to leave the trade and throw his lot in with people whose standard of living is somewhat higher. In this way his commercial instinct militates continually

\footnotetext{
${ }^{25}$ In particular, I will analyze neither Common's later writings on Jews in Races and Immigrants in the USA nor his personal relationship with Selig Perlman. Both topics are discussed by Fiorito, Orsi, and Chasse in their articles.
} 
against making active efforts to better the condition of his trade (p.327).

The Jew is also exceedingly abstract and metaphysical, and greatly interested in general principles. His union is always, therefore, except in time of a strike, a forum for the discussion of socialism and the philosophy of the labor movement (p.327).

These excerpts channel classical antisemitic tropes about Jewish economic behavior (Penslar 2000). From these and similar quotes, Fiorito and Orsi "feel confident" in adding Commons's name to other "great economists" who have been accused of antisemitism (Fiorito and Orsi 2016, p.56). I have shown, however, that Horovitz, Borochov, and Leshchinsky included exactly the same features in their descriptions of Jewish workers: physical weakness, a special taste for commerce and speculation, a lack of discipline, a higher standard of living, and excessive intellectual development.

I do not intend my contribution to this debate as a defense of Commons. The significant differences between the anti-sweatshop campaign and non-proletarianization theories are important. First, unlike Commons and other non-Jewish social reformers, Labor Zionists eschewed the language of race in their portraits of Jewish workers. They regarded Jews' alleged inaptitude for industrial work as grounded not in racial traits but, rather, in a national struggle and a lack of territorial autonomy, while non-Jewish activists stressed race as sweatshops' underlying cause (Bender 2004, p.44). This difference explains why non-proletarianization theories' general characterization of the Jewish workforce, though mostly negative, did not include the "most lurid images of Jewish racial inferiority" or the anxiety about Jewish immigrants" "germs" and "smell and filth" that appeared in the anti-sweatshop campaign (Bender 2004, p.49).

Importantly, Horovitz, Leshchinsky, and Borochov on the one side and authors such as Commons on the other side reached completely opposed political conclusions in their studies. Both sides - except for Borochov-agreed that the Jewish character severely impeded the social organization of labor. But Commons, like many Progressive Era reformers, advocated for a strong restriction of immigration - particularly by Eastern European Jews - while Labor Zionists sought, on the contrary, to increase, organize, and "concentrate" migration in a given territory.

Commons's and Labor Zionist's descriptions are similar regarding the rhetoric of "degeneration" and "regeneration" that cultural historian Todd Presner identifies in the period's Zionist discourse. Presner has shown how the Zionist ideal of the "muscle Jew"-a counterimage to Jews' alleged physical and moral weakness in the Diaspora - internalized many antisemitic stereotypes about Jewish degeneracy and took clear inspiration from the fascist fascination with "sane" and strong bodies. Yet, as Presner argues, this connection does not mean fascism and Zionism are at all equivalent, since their political goals differed entirely (Presner 2007, p.17). ${ }^{26}$

The similarities between Labor Zionists' and Commons's descriptions of Jewish workers do not, therefore, invalidate Fiorito and Orsi's general argument about Commons's antisemitism. However, as Presner has shown, they confirm that Jews can also internalize and be influenced by anti-Jewish stereotypes. Chasse seems to have ignored this basic principle. In his response to Fiorito and Orsi, Chasse points out that Commons, in preparing his report, spent six months with Abram Bisno, a Jewish garment worker and union leader. Chasse repeatedly asks in his article, "How can Commons be accused of anti-Semitism by using the words of a

\footnotetext{
${ }^{26}$ In particular, as Presner writes, "There was no external enemy that Zionism sought to annihilate" (Presner 2007, p.17).
} 
Jewish union leader?" (Chasse 2018 pp.424,426-427). Thus, he implies that Jews' antisemitic opinions are self-contradictory. ${ }^{27}$ However, both Jewish and non-Jewish authors can share similar prejudices and influence each other. Though Commons and other Progressive Era social scientists were unlikely to have read Labor Zionist pamphlets in Yiddish, conversely, Labor Zionists were likely inspired by non-Jewish social science. In Jewish Worker in London, for instance, Leshchinsky quoted Webb's survey of London's Jewish community, which included similar comments about Jews' "mental agility," "trained intellect, admirably adapted to commerce and finance," and "lack of social morality," which she suggested was responsible for their concentration in the sweating system (Webb 1889, pp.586-589; Leshchinsky 1907, pp.17$18)$.

Another important lesson from the comparison between the anti-sweatshop discourse and non-proletarization theories is the difficulty - if not impossibility - of distinguishing antiJewish prejudice from "sound" economic thinking. This difficulty complicates both sides of the controversy. On the one hand, Chasse strives to demonstrate that many of Commons's arguments against Jewish and non-Jewish immigration were "reasonable" and grounded in concrete observations. For instance, he cites the idea that immigration was pro-cyclical or that it complicated labor organization among workers of many nationalities (Chasse 2018, p.423). Chasse also considers some of the terms Commons used to have had no negative sense. For example, he discusses the word "individualism," which was not "synonymous with "selfishness" or "uncooperativeness"” and had no "pejorative sense" (Chase 2018, p.426).

Chasse's reading overestimates the degrees of consistency and coherence in these alleged characters of the Jewish worker. In Labor Zionists' writings, portraits of the Jewish worker were vague and ambivalent. For instance, Leshchinsky frequently related Jews' "mental agitation" to their lack of discipline and inaptitude for industrial work while also associating, in different contexts, their "intellectual agility" (neshome rirevdikayt) with such positive qualities as a sense of innovation and an adaptive or entrepreneurial spirit (e.g., Leshchinsky 1931, p.16). As Leshchinsky wrote, "The desire to rise can be either an inclination to evil [yeytser-hore] or inclination to good [yeytser-hatov]" (Leshchinsky 1938, p.180). Borochov, like Leshchinsky, constantly referred to Jewish bodies' alleged physical inferiority, but he sometimes criticized the idea of Jewish reluctance toward physical work, emphasizing the long Jewish tradition of manual work (e.g., Borochov 1916, p.180). These paradoxes and contradictions are, again, consistent with Presner's observations on "Muscular Judaism" as a "deeply conflicted ideal" (Presner 2007, p.17).

Fiorito and Orsi are aware of antisemitism's often conflicting and contradictory nature, referring to the notion of "ambivalent antisemitism" that was first popularized in the history of economic thought by Melvin Reder's article about John M. Keynes, Friedrich Hayek, and Joseph Schumpeter (Reder 2000). Yet their approach is still morally framed at the individual level. They treat antisemitism as a set of personal beliefs and prejudices by a single author. They seek to determine whether Commons is among the famous economists who held morally reprehensible ideas about Jews.

The corpus of non-proletarization theories suggests that this repertoire of anti-Jewish economic tropes cannot be well understood as private, personal obsessions among individuals who were - aside from these prejudices - "great economists." Though vague and mutable, these images of the Jewish worker were extremely influential, and they echo throughout social

\footnotetext{
${ }^{27}$ More generally, in my opinion, an important drawback to both Fiorito and Orsi's and Chasse's articles is their neglect of the literature on Jewish history. In particular, they seem to ignore the study of the writings of Bisnowho played a central role in their controversy - in relevant and well-known studies of the secondary literature (e.g., Bender 2004; Goldstein 2006, p.82) and, therefore, to miss important information - notably the fact that Bisno had, previously to Commons's report, testified to the US House of Representatives on the sweating system, as he wrote about later in his memoirs.
} 
science. These images' pervasiveness illustrates what Presner calls the "intersectionality of discursive formations," multiple economic, statistical, eugenic, and aesthetic discourses that "related to and build off one another" (Presner 2007, p.19). Hence, non-proletarianization theories' folk-psychological considerations should not be regarded as undesirable, separable by-products of economic and statistical thinking. Rather, they were part of this thinking. Therefore, in my opinion, studying the origin and diffusion of these images and stereotypes offers a more promising approach. We can track their transformation from one group of authors to another-between Jews and non-Jews - to show how economic representations of Jews generally informed the history of economic thought. ${ }^{28}$

Beyond Commons's case, the anti-sweatshop discourse of social reform and nonproletarianization theories also aligned in a similar stance toward gender. Both in Eastern Europe and in immigration countries, women represented a significant part of the overall Jewish workforce (Glenn 1990; Bender 2004), especially in the garment industry (Green 1998). Women played also an important political role in the Jewish labor movement. They constituted a large part of the Bund's membership in Eastern Europe. ${ }^{29}$ In the United States, women worked at the forefront of the garment industry's major strikes in 1909-1913 (Glenn 1990, pp.167-205; Bender 2004).

Historian Daniel Bender argues that the anti-sweatshop campaign in the American Progressive Era sought to reinforce "conceptions of sexual difference." Against the sweatshop, social reformers promoted "an ideal of "separate spheres"' in which the home was understood as a reproductive space and the workplace was understood as a "productive space" (Bender 2004, pp.12-16). They maintained that women's work could be only transient, before marriage, and that men should remain the primary breadwinners.

A striking feature of non-proletarianization theories in this regard is that they almost completely ignored women-despite women's important economic and political roles. Leshchinsky seldom discussed women's work, toward which he held an ambivalent attitude at best. He saw the rise of Jewish female employment as a positive phenomenon of "productivization" (e.g., Leshchinsky 1937). But he worried about negative demographic consequences (e.g., Leshchinsky 1912c). Consistent with Bender's interpretation of the antisweatshop campaign, Leshchinsky also regarded women's work as the consequence of poverty. He pointed out that, in more affluent households, women did not have to work (e.g., Leshchinsky 1903, p.28). Thus, he suggested, men should serve as breadwinners. Borochov seems to have been interested in feminism, and he gathered notes on the subject (Cohen, 1984, p.33). However, with few exceptions (e.g., Borochov [ND] 1928, p.179; Leshchinsky 1937, p.66), discussions about non-proletarianization relied on the gender-neutral word worker (arbeter in Yiddish) and not female workers (arbetorins).

Thus, one could reasonably argue that Bender's interpretation extends to Labor Zionists' writings and that non-proletarianization's gender-neutral language came to refer to male workers only, reinforcing the ideal of male workers as the preferred breadwinners. This development also made the negative image of the "weak" proletarian a masculine counterimage. In this regard, Presner's remarks on the "muscle Jew" figure apply, too. The muscle Jew was a masculinist ideal, according to Presner, not because men were the only muscle Jews and women did not try to conform to the muscle ideal; rather, "it was Jewish men who were supposedly not strong enough, healthy enough, and fit enough" (Presner 2007, p.12). Similarly, one could argue that although Jewish women significantly participated in the labor movement, the Zionist proletarian was a masculinist ideal because men were uniquely targeted as "weak" workers.

\footnotetext{
${ }^{28}$ For a recent illustration of this approach, see Trivellato 2019 and also the 2015 mini-symposium on antisemitism and economic thought in Research in the History of Economic Thought and Methodology. ${ }^{29}$ See the estimations in Peled 1989, p.41; Glenn 1990, p.38.
} 


\section{POLITICAL AND THEORETICAL LEGACIES OF THE NON- PROLETARIANIZATION DEBATE}

Non-proletarianization theories in Labor Zionism peaked in the early 1900s. At the end of this decade, the movement's political influence faded away. In the years following the 1905 Revolution, many Labor Zionism leaders left the Russian Empire. By 1908, the Sejmists and the Zionist Socialist parties had largely disbanded (Trachtenberg 2008, p.38). As early as 1905, Horovitz abandoned the ideas of mass emigration and territorial concentration and expected legal improvement and normalization of the Jewish economy in Russia from capitalism's further advance (Gutwein 1994, p.106). He then became active in the Jewish cooperative movement in Russia (Slutsky 2007, p.534).

Leshchinsky changed his mind, too. He gradually departed from the Labor Zionist movement in the late 1900s (Manor 1961, p.46). During World War I, he came to consider the "non-productive" elements of the Jewish workforce to be transitioning into productive factory work in Eastern Europe (Estraikh 2009, p.11). Such positive views of the Jewish economy in the Diaspora became more and more frequent in Leshchinsky's writings of the late 1910s and early 1920s (e.g., Leshchinsky 1921, esp. pp.18-24; Leshchinsky 1923; Leshchinsky [1928] 2020; Leshchinsky [1931] 2020).

Horovitz and Leshchinsky's political evolution can be read as predictive failures of their earlier views. In retrospect, many of the 1900s' proletarianization theories proved wrong. These theories failed, notably, to anticipate Jewish immigrants' successful integration into the United States and their active participation-especially among young women-in the major strikes of the US garment industry in 1909-1913 (Bender 2004). According to Yoav Peled, the Zionist Socialist diagnosis of non-proletarianization suffered from one weakness: "reifying" Jews' economic situation in Russia and identifying "national antagonism" as the major factor preventing "understanding the dynamics, rather than only the statics, of the Jewish condition" (Peled 1989, p.91).

Bundist demographer Liebmann Hersch formulated a similar critique in a 1927 letter to Leshchinsky. He suggested that the Zionist Socialists had fundamentally erred in considering the "national antagonism between Jewish and Christian workers" as an "inevitable outcome life in the Diaspora," overstating its significance, while the Bund had correctly identified this antagonism as a "historical and transient phenomenon." 30 From Hersch's Bundist perspective, territorialism was no solution. Jews had to fight for socio-economic justice in Russia and Poland. Leshchinsky, indeed, moved closer to such Bundist positions as a result of his slightly less pessimistic outlook on Jewish life in the Diaspora. ${ }^{31}$

Conversely, Borochov seems to have offered a more effective practical solution to the problem of Jewish non-proletarization relative to Leshchinsky and Horovitz's initial conjectures. The pro-Palestine wing of Labor Zionism ultimately had a much brighter future. Only in Palestine was a significant concentration of the Jewish workforce achieved. Many of Borochov's former disciples-including David Ben Gurion and Golda Meir-became dominant figures in Palestine and the future state of Israel. ${ }^{32}$ Despite his early death in 1917 , Borochov is now remembered as the main inspirational leader of Labor Zionism.

Yet the territorialist factions' political failure and Borochov's relatively successful lineage do not suggest that Borochov's camp better interpreted the data in the early 1900s.

\footnotetext{
${ }^{30}$ Liebmann Hersch to Yakov Leshchinsky, 11 October 1927. YIVO Archive. Papers of Jacob Leshchinsky, RG 339, Folder 11.

${ }^{31}$ Yakov Leshchinsky regularly contributed to the journals of the Polish Bund, though he was not formally a member of the Party (unlike his brother Yosef).

${ }^{32}$ Among these dominant figures, three prime ministers and two presidents of the State of Israel had been veteran party members of the Poale Zion (Frankel 1984, p.330).
} 
Rather, they resulted from the largely unexpected events of the following decade. After the outbreak of World War I and the Balfour Declaration, the idea of a Jewish national territory outside Palestine became increasingly unrealistic and irrelevant to the new era's Zionist agenda (Alroey 2011). The creation of both the Soviet Union and the independent state of Poland promised that the former Russian Empire's national minorities - including Jews - could be recognized and afforded some form of cultural autonomy. Many former Labor Zionists turned to "Diaspora nationalism," seeking to defend Jews' political and cultural rights in their countries of residence while preserving a favorable attitude toward Zionism. This new agenda led the Zionist Socialist Party to abandon territorialism and amalgamate, in 1917, with the Sejmists to form the Fareynikte (United) Party (Guterman 1985, pp.9-10). ${ }^{33}$

World War I and the 1917 Revolution, thus, completely changed the political debate for Jews in Russia, blurring the former ideological proclivities between Labor Zionism's various factions and even between non-Zionist and Zionist socialists. Indeed, many former members of these parties renounced their political affiliations in the interwar period, and through their practical works, approached both the Bund and Zionism (Alroey 2006, p.80). ${ }^{34}$ Leshchinsky notably underwent this kind of transition. After a short period of political activity in 1917-1918 in the Fareynikte - which explicitly relinquished territorialism - he moved to Berlin. There, he abandoned all political affiliations (Estraikh 2007, p.222). He continued his numerous economic and statistical activities while remaining active in various Jewish relief agencies. These organizations displayed considerable ideological and political flexibility. For instance, the ORT - which sought to promote Jews' professional training in the Diaspora - found supporters with a large spectrum of political tendencies: "enlightened" liberals, Bundists, and also territorialist or even Zionists and communists (Estraikh 2009).

This political blurring does not mean, however, that Leshchinsky and his comrades' political trajectory was completely inconsistent or fortuitous. As a journalist and statistician, Leshchinsky came naturally to revise his positions, depending on modifications to economic and political circumstances. Yet, overall, Leshchinsky's political outlook remained fairly consistent. He remained committed to the idea of directing Jewish emigration from Russia to new places for territorial concentration. That idea may have temporarily disappeared from his political views during World War I, but Leshchinsky quickly reemerged as a leader in the Berlin-based organizations dedicated to organizing Jewish emigration in 1921 ( Saß 2012, pp.215-224). In the mid-1920s, his optimism about Jewish economic "productivization" in the Diaspora ended (e.g., Leshchinsky 1925a, pp.89-90; Leshchinsky 1925b) ${ }^{35}$ His economic reports became increasingly pessimistic in the 1930s, with the rise of nationalism and fascism in Europe (e.g., Leshchinsky 1933; 1936). Leshchinsky thus favored renewed territorialism in the years preceding World War II. He sympathized, for instance, with positions defended by his long-time political comrade Ben-Adir (Avrom Rozin, a leading Sejmist figure), the Fareynikte, and ultimately the territorialist association known as Frayland-lige (the Freeland League, founded in 1935). ${ }^{36}$

\footnotetext{
${ }^{33}$ The two parties quickly resurfaced in 1917-1920 (Mintz 2010).

${ }^{34}$ Leshchinsky became more sympathetic to Zionism toward the end of his life (see Leshchinsky 1959). He immigrated to Israel in 1959 and died there in 1966. On Leshchinsky's changing attitude toward Zionism, see Alroey 2006. Another illustration of this political blurring is the trajectory of Yosef Leshchinsky, also a former member of the Zionist Socialist Party, who became a prominent figure of the Polish Bund in the interwar period. ${ }^{35}$ Note, though, that as late as 1931, in his book The Economic Situation of the Jews in Poland, he defended the idea of positive economic prospects for Jews in Poland.

${ }^{36}$ Both Leshchinsky and Ben-Adir agreed, for instance, on the idea of a World Jewish Congress that should be dedicated to the problem of Jewish colonization (Ben Adir to Leshchinsky, 16 June 1938. YIVO Archive. Papers of Jacob Leshchinsky, Folder 8). Leshchinsky also published materials about the colonization project in EnglishGuinea, at the behest of Ben Adir (Ben Adir to Leshchinsky, 23 May 1939. YIVO Archive. Papers of Jacob Leshchinsky, Folder 8).
} 
This political consistency is exemplified in the introduction to Leshchinsky's 1933 book At the Edge of the Abyss, where he recalled that he had written an article with the same title "twenty-one years" ago, in 1906. Leshchinsky regretted then, in 1933, that the situation had worsened: "Nowadays, European Jewry is not at the edge, but already deep, very deep inside the abyss" (Leshchinsky 1933, pp.10-12). Notwithstanding this further degradation, Leshchinsky also stressed that he remained committed throughout his whole life to the "emigration doctrine" - that is, the idea that European Jews had no future apart from "the exit out of Europe" (Leshchinsky 1933, p.12).

This consistency was not only political but also intellectual. Economic debates among early-1900s Labor Zionists had a theoretical legacy. From this perspective, nonproletarianization theories' most enduring contribution was perhaps not political answers and forecast based in statistics but, rather, establishing non-proletarianization as a scientific notion. In his letter to Leshchinsky, Hersch wrote that the Zionist Socialists "raised the [correct] question, the correct answer came from the Bund." 37 This opinion might have been true-at least from Hersch's perspective - but one could argue that Leshchinsky and other Labor Zionists' long-term intellectual influence precisely drew attention to this specific issue of Jewish access to large-scale industrial work. In Jewish economic historiography, this influence could have enforced the idea that, first, this issue was Jews' main economic problem ${ }^{38}$ and, second, that this discussion had to be informed by quantitative knowledge.

This particular framing determined how statisticians and economists assessed the favorability of Jews' economic situation generally. I have shown that, in these theories' early days, economic research on Jewish non-proletarianization was mostly based on pre-existing, late-nineteenth-century statistical sources - particularly from the JCA report and the Russian census. These data's focus on non-proletarianization led Labor Zionists to focus on indicators such as numbers of workers per factory, factory and workshop size, and the relative importance of Jewish employment in producing consumer goods versus the means of production, or salaried workers' prevalence over independent workers.

In the 1930s, this intellectual tradition evolved into a more mature research program when Leshchinsky, as the head of the Economic-Statistical Section of the YIVO, became capable of conducting large-scale surveys about Polish Jews' economic situation and producing his own statistics. Yet he essentially maintained the same focus. Leshchinsky and his collaborators at the YIVO explicitly regarded the proletarianization and non-proletarianization processes as central topics in their scientific agenda. ${ }^{39}$ This priority clearly reflected in Yiddishe ekonomik, the economic periodical published by the section and edited by Leshchinsky. This consistency in empirical research clearly shows that non-proletarianization theories survived their initial predictive failure and succeeded in presenting non-proletarianization as a stable scientific notion.

Another important element of consistency in this intellectual tradition is the reliance upon folk-psychological arguments about Jewish workers' "character." In his later works, Leshchinsky repeatedly referred to such arguments. Although he observed that this "spirit" had changed (Leshchinsky 1933, pp.211-215), he never abandoned the idea of a specific and inherited mentality among Jewish workers. For instance, in a 1938 article, he wrote that the fundamental cause for the Jews" "avoidance of the factory and strive toward craft professions" was the "desire to rise" on the social ladder, which was significantly more ingrained in the

\footnotetext{
${ }^{37}$ Liebmann Hersch to Yakov Leshchinsky, 11 October 1927. YIVO Archive. Papers of Jacob Leshchinsky, Folder 21.

${ }^{38}$ See, for instance, Tartakower 1972.

${ }^{39}$ See, for instance, Minutes and notes from the Central Board session, 8-10 October 1938, R.G. 1.1. Records of YIVO (Vilna): Administration.
} 
Jewish masses (Leshchinsky 1938, p.175 and p.180). ${ }^{40}$

This continuous folk-psychological frame in Leshchinsky's works-and, more generally, in non-proletarianization theories-leads me to disagree partially with Daniel Gutwein's interpretation. In his article on Borochov and the development of nonproletarianization theories, Gutwein opposed these theories' two respective versions by Leshchinsky and Horovitz. According to Gutwein, Horovitz would consider "national struggle" only as an indirect cause of non-proletarianization and would focus more on "psychological causes" that shape Jews" "national character," while Leshchinsky would regard national struggle as a direct cause produced by a "real economic" process on the market (Gutwein 1990, p.160). In my opinion, the opposition between two explanatory schemes-respectively, psychological and Marxist or economic - does not seem operative to me in this intellectual tradition, which distinguished itself precisely with its mixture of folk-psychological considerations and statistical-economic arguments.

\section{CONCLUSION}

In responding to the Russian Jewry's socio-economic crisis in the late nineteenth century, Horovitz, Leshchinsky, and Borochov proposed different reflections on Jewish workers and their entry into the capitalist economy. Borochov criticized Horovitz and Leshchinsky's non-proletarianization theories for their excessive pessimism. Yet the three authors' writings were all influenced by and dependent upon recent developments in statistics. Alongside numbers and empirical evidence, discourses about Jewish non-proletarianization were also replete with folk-psychological considerations about Jews' "national character." Such considerations were very similar to aspects of the anti-sweatshop campaign at the turn of the century, which blamed Jewish immigrants for the "sweating system" and its poor working conditions. Unlike Progressive Era social reformers and economists, such as Commons, Labor Zionists eschewed the language of race and participated in a more enduring Jewish intellectual tradition that framed non-proletarization as a statistical category, transforming it into a scientific notion.

\section{Acknowledgements:}

I would like to thank Robert Brym, Gur Alroey, Gennady Estraikh, Axelle Neyrinck, Cléo Chassonnery-Zaïgouche, François Allisson, the two anonymous referees and participants at the 2020 REhPERE seminar. Remaining errors are my own.

\footnotetext{
${ }^{40}$ Note, though, that in the very same 1938 issue of Yiddishe ekonomik, edited by Leshchinsky, Menahem Linder and Hersch Szner criticized the idea that the Jewish desire to "rise on top of the mountain" would explain Jews' excessive concentration in light industries and craft production (Linder and Szner 1938, pp.223-224). Instead, they blamed a lack of qualification and professional training. They did not explicitly name Leshchinsky-who was the editor of the review_- though he had clearly long held this belief.
} 


\section{References}

Allisson, François, and Antoine Missemer. 2020. "Some historiographical tools for the study of intellectual legacies." Studies in History and Philosophy of Science Part A.

Alroey, Gur. 2006. "Demographers in the service of the nation: Liebmann Hersch, Jacob Lestschinsky, and the early study of Jewish migration." Jewish History 20(3-4): 265-282.

Alroey, Gur. 2011. "“Zionism without Zion"? Territorialist Ideology and the Zionist Movement, 1882-1956." Jewish Social Studies 18(1) (2011): 1-32.

Aronson, Michael. 1990. Troubled waters: Origins of the 1881 anti-Jewish pogroms in Russia. Pittsburgh: University of Pittsburgh Press.

Borochov, Ber. [1907] 1928. "Di role fun dem arbeter-klas in der realizirung funem teritorializm." In Geklibene shriftn, New York: Yiddish natsyonaler arbeter-farband, pp.3-37 (Yiddish). heym (Yiddish).

[1916] 1919. "Di ekonomishe antviklung fun yudishn folk." Warsaw: Arbeyter [1916] 1923. "Di yiddishe arbeter bavegung in tsifern.” Berlin: Farlag Ferdinand Ostertag (Yiddish).

[undated] (1928), "Vos ken men ton kegn der aroyshtoysung?" In Geklibene shriftn. New York: yiddish natsyonaler arbeter-farband, pp.179-186 (Yiddish).

1984. Selected Essays in Marxist Zionism. Edited by Mitchell Cohen, New Brunswick: Transaction Publishers.

Bender, Daniel E. 2004. Sweated work, weak bodies: anti-sweatshop campaigns and languages of labor. London: Rutgers University Press, 2004.

Brym, Robert. 1978. Jewish Intelligentsia and Russian Marxism: A Sociological Study of Intellectual Radicalism and Ideological Divergence. New York: Springer.

Cadiot, Juliette. 2004. « Le recensement de 1897. Les limites du contrôle impérial et la représentation des nationalités. » Cahiers du monde russe 45(3-4): 441-464.

Charney, Shmuel. 1906. "Vos iz azoyns der yiddisher arbeter?” Vilna: Tsukunft (Yiddish).

Chasse, J. Dennis. 2018. "What does it mean? A comment on the alleged anti-semitism of John R. Commons." Journal of the History of Economic Thought 40(3):419-432.

Cohen, Mitchell. 1984. "Introduction”, in Ber Borochov - Selected Essays in Marxist Zionism. New Brunswick: Transaction Publishers.

Commons, John R. 1901. "Immigration and Its Economic Effects." In Reports of the U.S. Industrial Commission. Volume 15. Washington: Government Printing Office, pp. 293 - 743.

de Lagerie, Pauline Barraud. 2013. "The wages of sweat: A social history perspective on the fight against sweatshops." Sociologie du travail 55: 1-23.

DellaPergola, Sergio. 1997. "Some fundamentals of Jewish demographic history." Papers in Jewish demography pp.11-33.

Estraikh, Gennady. 2007. "Jacob Lestschinsky: A Yiddishist Dreamer and Social Scientist”, Science in Context 20(2): 215-237. 
Estraikh, Gennady. 2009. "Changing ideologies of artisanal "productivisation": ORT in late imperial Russia." East European Jewish Affairs 39(1): 3-18.

Fiorito, Luca, and Cosma Orsi. 2016. "Anti-Semitism and Progressive Era Social Science: The Case of John R. Commons." Journal of the History of Economic Thought 38(1): 55-80.

Frankel, Jonathan. 1984. Prophecy and politics: socialism, nationalism, and the Russian Jews, 1862-1917. New York: Cambridge University Press.

Glenn, Susan Anita. 1990. Daughters of the shtetl: Life and labor in the immigrant generation. Ithaca: Cornell University Press.

Goldstein, Eric L. 2006. The price of whiteness: Jews, race, and American identity. Oxford: Princeton University Press.

Gozhansky, Shmul. 1903. Der tsionizm. London: The Bund (Yiddish).

Green, Nancy L. 1998. Du Sentier à la 7e Avenue: la confection et les immigrés, Paris-New York, 1880-1980. Paris : Éd. du Seuil.

Guterman, Alexander. 1985. Ha-miflagah ha-tsiyonit-sotsialistit be-rusya (S.S.) bashanim 1905-1906. Tel Aviv: Peretz (Hebrew).

Gutwein, Daniel. 1990. "Proleitarizatsiah u-folitizatsia: Borochov u-megamot lehitpatkhutah shel teioreit ha-i-proletarizatsiah." Shvut 14: 141-186 (Hebrew).

Gutwein, Daniel. 1994. "Economics, Politics and Historiography: Hayyim D. Horowitz and the Interrelationship of Jews and Capitalism." Jewish Social Studies 1(1): 94-114.

Horovitz, Khaim Dov. 1902a. "Sheelat ha-kalkalah u-mekomah be-tenuatenu ha-leomit." Hashiloakh 9: 17-32 (Hebrew).

$1902 b$. 130-149 (Hebrew).

1902c. 305-320 (Hebrew).

1902d. "Sheelat ha-kalkalah u-mekomah be-tenuatenu ha-leomit." Hashiloakh 10: 57-72(Hebrew).

$1902 \mathrm{e}$ 110-127 (Hebrew).

$1902 f$. 328-337 (Hebrew). $1902 \mathrm{~g}$. 400-412 (Hebrew).

Jewish Colonization Association. [1904] 1906. Recueil de matériaux sur la situation économique des Israélites de Russie, tome 1. Paris : Félix Alcan.

1908. Recueil de matériaux sur la situation économique des Israélites de Russie, tome 2. Paris : Félix Alcan.

Karp, Jonathan. 2008. The Politics of Jewish Commerce. Economic Thought and Emancipation in Europe, 1638-1848. Cambridge: Cambridge University Press.

Katz, Dovid. 2010. "Borokhov, Ber." YIVO Encyclopedia of Jews in Eastern Europe, https://yivoencyclopedia.org/article.aspx/Borokhov_Ber.

Kleiman, Ephraim. 1973. “An Early Modern Hebrew Textbook of Economics.” History of Political Economy 5(2): 339-358.

Klier, John Doyle, and Shlomo Lambroza (eds). 1992. Pogroms: Anti-Jewish violence in modern Russian history. Cambridge: Cambridge University Press, 1992. 
Linder, Menahem and Szner, Hersch. 1938. "yiddishe arbet in yiddishe industriunternemungen" Yiddishe ekonomik 2(5-6): 201-224.

Lederhendler, Eli. 2009. "Jewish immigrants and American capitalism, 1880-1920: from caste to class." New York: Cambridge University Press.

Leshchinsky, Yakov. [1903] (1960. "Statistikah shel ha-yarah akhat." In Ha-tfutsah hayehudit - Ha-hitpatkhut ha-khavretit ve-hakalkalit shel kibutsei ha-yehudim be-eyropa uveamerika bedorot hakharonim. Jerusalem: Bialik Institute, pp.1-32 (Hebrew).

1906. Der yiddisher arbeter in rusland. Vilna: Tsukunft (Yiddish).

1906. Der yiddisher arbeter in london. Vilna: Tsukunft (Yiddish).

1912a. "Fun ekonomishen lebn." Haynt, November 15, p.4 (Yiddish).

1912b. "Ha-yehudim begermania." Ha-olam, November 26, p.5-6 (Hebrew).

1912c. "Ha-yehudim begermania", Ha-olam, 19 septembre (Hebrew).

1913. "Zur Psychologie des jüdischen Auswanderers," Zeitschrift für Demographie und Statistik der Juden, 5: 75-80.

1921. Dos yiddishe ekonomishe leben in der yiddishe literatur. Warshaw: Kultur Lige (Yiddish).

1923. "Di oyfgaben fun der yiddisher statistik." Bleter far yiddishe demografye, statistik un ekonomik 1: 1-4 (Yiddish).

1925a. "Di ekonomishe lage fun di yidn in mizreykh-eyropa." Bleter far yidishe demografye, statistik un ekonomik 5: 81-103 (Yiddish).

1925b. Der emes vegn di yidn in rusland. Berlin: Lutze \& Vagt (Yiddish).

[1928] 2020. "The development of the Jewish People over the last 100 years." Eastern European Jewis Affairs 50(1-2): 157-142. Translated by Robert Brym.

1931. Di ekonomishe lage fun yidn in poyln. Viktoria: Berlin (Yiddish).

[1931] 2020. The Economic Situation of the Jews in Interwar Poland.

Lexington KY: Kindle Direct Publishing. Translated by Robert Brym.

[1933] 1947. Oyfn rand fun opgrund. Fun yiddishn leben in poyln (1927-1933).

Buenos Ayres : Tsentral farband fun poylishe yidn in argentine (Yiddish).

1937. "Di yidn in varshe." Yiddishe ekonomik 1(4-5) : 158-176.

1938. "Di yidn in varshe un lodz." Yiddishe ekonomik 2(3-4) : 156-181.

1959. Ha-demut ha-leomit shel yahadut ha-golah. Y.L. Peretz: Tel Aviv.

Mahler, Raphael. 1967. "Yankev Leshchinsky: Der klasiker fun der yiddisher statistik," in Historiker un vegvayzer: eseyen, Tel Aviv: Israel-Book, 184-195.

Manor, Alexander. 1961. Yakov Leshchinsky: ha-hogeh va-hakhoker. Jerusalem: World Jewish Congress (Hebrew).

Mendelsohn, Ezra. 1970. Class Struggle in the Pale: The Formative Years of the Jewish Worker's Movement in Tsarist Russia. Cambridge: Cambridge University Press.

Mintz, Matityahu. 1976. Ber Borochov: ha-maagal ha-rishon (1900-1906). Tel Aviv (Hebrew). 
Nordau, Max. [1909], 1923. "V. Kongressrede.” In Max Nordau, Zionistische Schriften. Cologne : Zionistischen Aktionskommittee: 112-139.

Mintz, Matityahu. 2010. "Fareynikte." YIVO Encyclopedia of Jews in Eastern Europe, https://yivoencyclopedia.org/article.aspx/Fareynikte

Norman, Theodore. 1985. An outstretched arm: a history of the Jewish Colonization Association. New York: Routledge \& Kegan Paul Books.

Presner, Todd. 2007. Muscular Judaism: the Jewish body and the politics of regeneration. New York: Routledge, 2007.

Peled, Yoav. 1989. Class And Ethnicity In The Pale: The Political Economy Of Jewish Workers' Nationalism In Late Imperial. New York: St Martin's Press

Orechov S. 1957. "Dr. Ch. D, Horovitz, kalkalan ve-sofer." Heavar (Quarterly for the Study of the History of Russian Jews): 149-151. (Hebrew).

Slutzky, Yehuda. 2006. 'Horowitz, Hayyim Dov.” In Skolnik Fred et Michael Berenbaum, (eds), Encyclopaedia Judaica, Detroit: Macmillan Reference: 534, volume 9.

Stern, Eliyahu. 2018. Jewish Materialism: The Intellectual Revolution of the 1870s. New Haven: Yale University Press.

Tartakower, Arieh. 1972. Khalutsei ha-historiografiah ha-yehudit ha-kalkalit lezekherem hamevurakh shel Yakov Leshchinsky ve-shel Ytzhak Shipper. Jerusalem: Newman. (Hebrew)

Trachtenberg, Barry. 2008. The revolutionary roots of modern Yiddish, 1903-1917. Syracuse: Syracuse University Press, 2008.

Trivellato, Francesca. 2019. The promise and peril of credit: what a forgotten legend about Jews and finance tells us about the making of European commercial society. Princeton: Princeton University Press.

Vallois, Nicolas, and Imhoff Sarah. 2020. "The Luftmentsh as an Economic Metaphor for Jewish Poverty: A Rhetorical Analysis.” Working Paper, SocArXiv. doi:10.31235/osf.io/ptxgf.

Vallois, Nicolas. 2021a. "Jewish Social Science And The Analysis Of Jewish Statistics In The Early Twentieth Century." Journal of the History of Economic Thought 43(1): 1-26.

Vallois, Nicolas. 2021b. "Statistics, race and essentialism in the debate over Jewish employment structure (1902-1939).” Forthcoming in Jewish Social Studies.

Webb, Beatrice Potter. 1889. "The Jewish Community”. In Charles Booth (ed.), Life and Labour of the People in London. London and Edimburg: Will iams \& Norgate: 564590.

Wininger, Salomon. 1928. Große Jüdische National-Biographie. Czernowitz: Arta. 